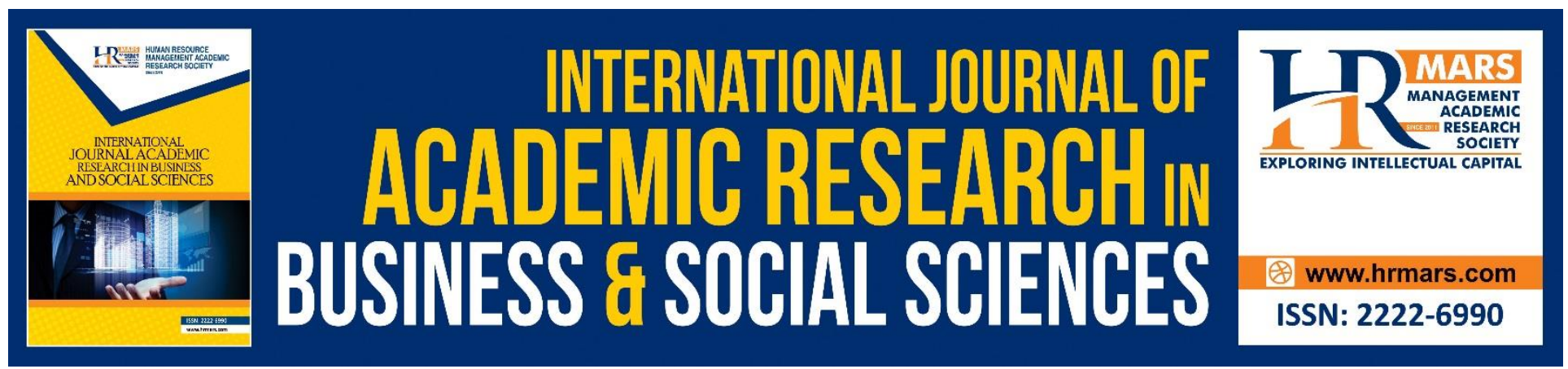

\title{
Sustainable Practices for Existing Building: Perspective of Local Authorities in Malaysia
}

Nurul Faizah Hamzah, Mohamad Sufian Hasim, Kwong QI Jie

To Link this Article: http://dx.doi.org/10.6007/IJARBSS/v8-i8/4627

DOI: $\quad 10.6007 /$ IJARBSS/v8-i8/4627

Received: 24 June 2018, Revised: 19 July 2018, Accepted: 29 July 2018

Published Online: 08 August 2018

In-Text Citation: (Hamzah, Hasim, \& Jie, 2018)

To Cite this Article: Hamzah, N. F., Hasim, M. S., \& Jie, K. Q. (2018). Sustainable Practices for Existing Building: Perspective of Local Authorities in Malaysia. International Journal of Academic Research in Business and Social Sciences, 8(8), 710-724.

Copyright: (C) 2018 The Author(s)

Published by Human Resource Management Academic Research Society (www.hrmars.com)

This article is published under the Creative Commons Attribution (CC BY 4.0) license. Anyone may reproduce, distribute, translate and create derivative works of this article (for both commercial and non-commercial purposes), subject to full attribution to the original publication and authors. The full terms of this license may be seen at: $\underline{\text { http://creativecommons.org/licences/by/4.0/legalcode }}$

Vol. 8, No. 8, August 2018, Pg. $710-724$

Full Terms \& Conditions of access and use can be found at http://hrmars.com/index.php/pages/detail/publication-ethics 


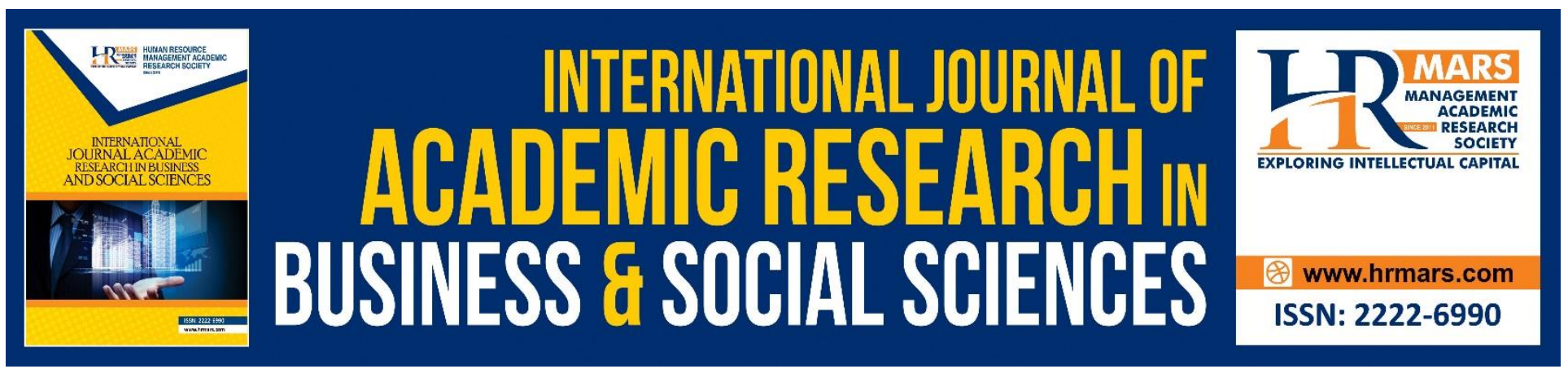

\title{
Sustainable Practices for Existing Building: Perspective of Local Authorities in Malaysia
}

\author{
Nurul Faizah Hamzah, Mohamad Sufian Hasim, Kwong QI Jie \\ Faculty of Architecture, Planning \& Surveying, Universiti Teknologi MARA, 40450 Shah Alam, \\ Selangor, MALAYSIA
}

\begin{abstract}
The progressive growth off building stocks over a period should not be ignored, because the implications have already affected the environment, economy and social aspect of the sustainable goal. Today, people, building, organisations and environment affected demands a holistic changes and improvement that need to be taken seriously. Adoption of sustainable practices in existing buildings specifically building owned by the government is a sign of sustainable commitment being practised and cultivates the appropriate approach. Such implementation should enhance the performance of local authority role and the existing building performance. This study discovered the area of concern that can enhance the sustainable practices implementation in local authority existing building. Data collected through interview (semi-structured) interviewed with 10 participants ranging from building managers, officers or senior officers. The result was generate using content analysis method. 16 sustainability Initiatives were discovered which demonstrate some significant effort from local authorities in managing their existing building. However, the effort still lacking to lead in becoming a role model towards sustainability. These organisation required more improvement and additional adoption to lead in sustainable practices. Hence, measuring the effectiveness of the practices should be explore including developing a model as guidance for this organisations to adopt towards becoming sustainable champion.
\end{abstract}

Keywords: Sustainable Initiatives, Existing Building, Local Authorities, Environment and Building Performance.

\section{Introduction}

Sustainability has been broadly discussed and highlighted as one of the world agenda in shaping the future needs. This issue was debated, discussed and reported worldwide to instill the thinking and adoption of sustainability in daily life and yet broaden the concept to the business, country and worldwide application. Recently, the sustainability agenda become more significant due to global issues that affect the whole world currently and affected the future (Forum,2014). Existing buildings contributed to the issues relating to sustainable agenda. Wood (2011), mentioned that sustainability could not achievable without addressing the existing building stock. Wood (2011) has been informed that even if every new building were a "sustainable building, their impact on sustainability as a whole 
would be minimal for some time compared to existing building. The rising of building stocks requires proper attention due to its impact on the environment in the long run. Presently, buildings contribute as much as one-third of total global greenhouse gas emissions, primarily through the use of fossil fuels during their operational phase (United Nations Environment Programme, 2009). Overall, the building sector reported to contributes up to $45 \%$ of global annual greenhouse gas emissions (Wu $\&$ Low, 2010) and need to be addressed properly mainly by local authorities. Thus, acted as role model in the local sustainable agenda, the changes should begin from the local authorities. Therefore, this study examines the current initiatives practices by local authorities in existing building. This study limits only to local authorities that claimed to become a sustainable city and committed to reduce carbon emission in the respective territories. The study also focuses on the perspective of the building managers and officers of the local authorities building.

\section{Literature Review}

Reckless development and industrialisation had abolished a million acres of forest, leveled of hills, destroyed of habitats, changed the river flow just to keep the awesome of development planning, changes of land use and many other had jeopardised all the natural conditions our beloved earth (Shahzad, 2015). The rising level of global carbon emission recorded from 1900 to 2010 prove this condition (Boden et.al.,2015). In fact, Ring et.al., (2012), mentioned that in 20th Century the human forcing had worsened the global condition. If the human activities cannot be controlled, the reaction could be extremely worse than what had occurred today (Murtaza, 2015; Nwankwoala, 2015; Zein \& Chehayeb, 2015). J. Ring et al., (2012) states that another cause of global warming and climate change is not mainly from human activities but also natural variability, volcanic eruptions, and solar irradiance. Since our beloved earth has existed longer than we are, there are high possibilities of its natural agility process lead to deterioration of its normal condition according to the natural law. Therefore, it is important to make people aware and understand that, all these have directly impacted us today and our future if we just ignored it.

Today, Malaysia is also affected by the changes of global condition (Hashim, 2015). The visibility of the global implication began in early 2006 when Shah Alam, the capital city of Selangor was invaded by flooded. In 2007, a sustainable city in State of Johor faced the same condition and followed by Sarawak in 2011. The whole nation was surprised with huge flooded in a few respective states including Pahang, Kelantan and Terengganu in 2014. Besides flood, it also reported twister occurred at Kedah in 2014 and others crisis that becomes yearly issues including water crisis, rationing and bushfire. Furthermore, the low temperature recorded in a few districts in Kelantan that reached 18 $21^{\circ}$ Celsius had surprised the local community. These conditions indicate that Malaysia has also been affected by the global conditions. Thus, a holistic approach to overwhelm the global conditions desperately needed. However, it requires everyone contribution and efforts to realise the important of preserving and conserving this beloved earth.

The role of local authorities had been acknowledged as the change agent for sustainable agenda to be disseminated to the communities (Zein \& Chehayeb, 2015; Zein \& Chehayeb, 2015). In Malaysia landscape, Malaysia has taken the initiatives to implement Agenda 21 into the country's development planning and monitoring systems, using the five-year Malaysian Development Plans and the longterm Outline Perspective Plans (OPPs) which are carried out in a period of 10 years (Makmor et.al., 2012). Agenda 21 or known as Local Agenda 21 is a programed that forms a partnership between three parties, which are the Local Authority, the private sector, and the local communities in planning 
INTERNATIONAL JOURNAL OF ACADEMIC RESEARCH IN BUSINESS AND SOCIAL SCIENCES

Vol. 8, No. 8, August 2018, E-ISSN: 2222-6990 @ 2018 HRMARS

and implementing programmes and caring for the surrounding environment to achieve sustainable development (Kipli, 2006).

Malaysia's action in agenda 21 aims to expose the local community to issues related to sustainable development by providing environmental education and commitments to preserve and conserve the environment. The bottom-up concept with the involvement of communities in sustainability practices is the role of local government to cultivate the agenda. In fact, local authority has a strong connection and very near to communities (Atkinson, 2002) is undeniable. In addition, Chili \& Xulu (2015), mentioned there is notable research gap still exists despite the increased focus on local authorities, particularly regarding empirical research investigating the roles and responsibilities of local authorities in sustainability agenda. Thus, it is significant to discover sustainability practices in local authority itself before checking, auditing and implementing to others as prove that LA is leading toward achieving sustainable agenda.

To attain the sustainable goal is not impossible, but it required addressing the existing building issues. Today, the numbers of existing building stock increase worldwide and this contribute in distracting the sustainable goal. Thus, scientist and researcher need to join force to discover how to anticipate this condition where sustainable building not only for new building but also for existing building (Adeyemi, Martin, \& Kazim, 2014). Since existing buildings contribute to the major effect to the environment, cause high economic implication and causes the social effect to the people these issues need to be addressed. Although existing building recognises as one of the major contributor to carbon emission, the involvement of existing building in sustainable is still lacking (Durmus-pedini \& Ashuri, 2010).

\section{Current Practices}

Discoveries of sustainable initiatives among researcher are varied from one and another. Although the discoveries are varied, there are two categories of initiatives recognised by the researchers which are common initiatives and other additional initiatives. Writers on sustainability practices recognise that there are few major common initiatives that strongly highlighted are Energy Efficiency, Water Efficiency, Waste Management (Filippi \& Sirombo, 2015; Rughooputh, Cheeneebash, \& Mungroo, 2014; KOÇ, 2014; Abdallah et al., 2013 and Hasim \& Pullen,2011). In addition, (Filippi \& Sirombo, 2015; KOÇ, 2014; and Hasim \& Pullen, 2011) also claimed that Sustainable Policy, Sustainable Transport and Sustainable Facilities / Infrastructure is other common initiatives practice in existing building. However, there are few reseachers including Society, 2005; Gimenez, Sierra, \& Rodon, 2012; Jaehn, 2015, highligted that sustainable operation is another initiative that strongly effects on sustainable goal. All these common initiatives elaborated further as below:

\section{a. Energy Efficiency}

The demand of energy consumption has increase over a period and expectedly rising (Rajaniemi \& Ahokas, 2012). In a building, energy contributed 30\% in building operations. Energy efficiency efforts will contribute greater impact through design efficiency, equipment efficiency, building envelope efficiency, infrastructure efficiency and efficient technological (Akadiri, Chinyio, \& Olomolaiye, 2012; Aksamija, 2015). Replace or install equipment relating to energy enable to enhance existing building performance and offer major savings by using LED Bulb \& Lighting Intelligent System (Rácz, 2012; Menaria, 2014; Jadhav \& Chandwadkar, 2016; Patil \& Wani, 2016); HVAC System, chiller and district 
INTERNATIONAL JOURNAL OF ACADEMIC RESEARCH IN BUSINESS AND SOCIAL SCIENCES

Vol. 8, No. 8, August 2018, E-ISSN: 2222-6990 @ 2018 HRMARS

cooling system (Gang, Wang, Xiao, \& Gao, 2015); renewable energy (Hayter \& Kandt, 2011); garden roof (Rahman, Ahmad, Mohammad, \& Rosley, 2015; GSA (General Services Administration, 2011;Getter \& Rowe, 2006). In regard to this, energy audit also should not keep ignored. An energy audit provides detail information and conditions, assessment of building energy usage enable to assist building owners or manager for energy savings and improvement (Yan-ping, Yong, \& Changbin, 2009; Lamba \& Sanghi, 2015). This initiatives' should become the main priority for any existing building before venturing into any energy efficiency initiatives to ensure the investment benefited toward energy efficient is highly effective and efficient.

\section{b. Water Efficiency}

Water Efficiency is another initiative toward sustainable building. Water depletion become global issues as part of the impact of global warming and climate change. The literature reveals some water efficiency strategies can be employ to reduce the amount of water consumed through the building operational phase. However, the most preferable are first, by adopting grey water recycling in the building enable to enhance water consumption (Das, Bera, \& Moulick, 2015; Akadiri et al., 2012; Joustra, 2010; Gilmer et al., 2008) and reducing water pressure (Akadiri et al., 2012; Joustra, 2010; Gilmer et al., 2008 ; Works, 2009). Other than that, other additional initiatives practices including rainwater harvesting (Das et al., 2015; Akadiri et al., 2012; Joustra, 2010),plumbing fixtures (Akadiri et al., 2012; Gilmer et al., 2008; Works, 2009), water audit (Joustra, 2010; Gilmer et al., 2008; Works, 2009). In addition, the usage of cooling tower (Das et al., 2015; Works, 2009), install new technologies (Joustra, 2010; Works, 2009), practice plumbing maintenance (Works, 2009) and Green Roof also enable to contribute to water efficiency practices in existing building.

\section{c. Waste Management}

Waste is another issue that needs to be given priority. Human activity leads to the risen of waste per day per person that will be dumb off to the landfill. Part of human activities is in the building. Thus, waste management is another element of assessment for the sustainable building to control the numbers of waste transported to a landfill, reducing the effect of the environment due to gases produce from the landfill such as methane and carbon dioxide. Common practices relating to waste management is reduced, reuse and recycling and reduction of the waste stream (KOÇ, 2014; Akadiri et al., 2012; Standar, 2005) and composting (KOÇ, 2014). Although composting initiatives little studies reported relating to existing building, the practices widely used in a different context beyond existing building.

\section{d. Sustainable Policy}

Policy plays an important role as guidance to achieve a goal or mission. Vargas-Hernandez, Reza, \& Haj Ali, (2013) claimed that by having a policy, it enable to dictate how the individual should react and behave according to the specific goal or mission. Thus, it is important for any existing building to develop sustainable policy and comply with other related rule and regulation related to sustainability as voluntary proactive to make the existing building sustainable.

\section{e. Sustainable Transport}

Transportation contributes to effect on sustainable agenda. The usage of fuel, to operate any transport somehow harm to the environment and increasing the carbon emission, which directly causes green gashouse effect. Many initiatives under sustainable transportation claimed by 
INTERNATIONAL JOURNAL OF ACADEMIC RESEARCH IN BUSINESS AND SOCIAL SCIENCES

Vol. 8, No. 8, August 2018, E-ISSN: 2222-6990 @ 2018 HRMARS

researchers including using pool transport services for the daily operation, building accessible to public transport facilities, using green transportation and provide pedestrian walkway facilities. Hasim \& Pullen, (2011) mentioned that sustainable transport management practices including pool transport services and minimise transport usage counted as sustainable efforts. Meanwhile, Li, (2016) claimed that green transportation is transport that convenient, safe, efficient, low-pollution, humanised and diversified urban transportation system reflect the sustainable transportation and goal.

\section{f. Sustainable Facilities / Infrastructure}

Existing facilities or infrastructure contributes to effect environmental conditions. Engel-Yan. et. al., (2005) claimed that infrastructure systems are not considered as "combined facilities", but are designed independently by specialists in the individual areas (e.g., transportation, water distribution, wastewater treatment, or building design. In existing building, the existence of the infrastructure and facilities that are not design and built with the sustainable standard but can become sustainable by practising maintenance management (Sodangi, et.al., 2014). The practices enable to make building facilities and infrastructure up to date, improve performance from time to time, enhance asset and building life span as well as optimal operating cost (Chan, 2014; Adegbenga Adeyemi; Rozilah Kassim; David Martin, 2014).

\section{g. Sustainable Operation}

Sustainable Operation describes by Jaehn, (2015) as focusing on the operational (practices) which include functional and structural in an organisation that consider more than just economic purposes. This definition implies that organisation practices triple bottom line concept in all of its operational process either adopting a system such as ISO, 5S, Total Quality Management (TQM), Kaizen, Just in Time Operation (JIT) (Society, 2005). In addition, technologies advancement also contribute to sustainable Operation as it can improve work process, efficiency, save time, reduce resources, save cost and become more competitive (Drake \& Spinler, 2013).It clearly enables to transform the organisation (top management and employees) toward betterment by shaping the culture, ideology and practicality in daily process operation in all the supply chain. Yet, people in organisation aware and realise to align all work process toward supporting the strategic vision of the organisation. However this initiative may overlap others initiatives purposes and outcome but to the end benefits toward the sustainable goal and this initiative is still lacking defined and reviewed in the literature (Jaehn, 2015).

Other additional initiatives including Sustainability Reporting \& Monitoring (Filippi \& Sirombo,2015; (Hasim \& Pullen,2011); Sustainable Biodiversity / Ecological System and Emission Control / Pollution Prevention (Rughooputh, Cheeneebash, \& Mungroo, 2014; Hasim \& Pullen,2011); Sustainable / Green Purchasing / Procurement (Filippi \& Sirombo,2015; Hasim \& Pullen,2011); Green IT, Office (Rughooputh, Cheeneebash, \& Mungroo, 2014; Hasim \& Pullen,2011); Community Engagement; Sustainability Awareness Program / Project ; Established/Signed Commitment Internal \& External and Partnership / Collaborations With Other Parties (Filippi \& Sirombo,2015; Hasim \& Pullen,2011). The other initiatives includes creating Sustainability Position/Coordinator; Having Sustainability Committee; Sustainability Department/Office; Sustainability Research \& Education (Hasim \& Pullen,2011;); Safety \& Health Occupant; Maintenance Services; Space Efficiency (Filippi \& Sirombo, 2015); Site Planning and Sustainable Materials \& Resources (Rughooputh, Cheeneebash, \& Mungroo, 2014). Overall, there are variations of sustainable initiatives revealed by various researchers before 
INTERNATIONAL JOURNAL OF ACADEMIC RESEARCH IN BUSINESS AND SOCIAL SCIENCES

Vol. 8, No. 8, August 2018, E-ISSN: 2222-6990 @ 2018 HRMARS

being implemented in existing building. Despite these discoveries, there could be other additional initiatives that not included and an initiatives practice by the organisation is differing according to the country, organisation and industry.

\section{Research Methods}

This study focuses on local authorities' context. Although 154 local authorities were listed by Ministry of Urban Wellbeing, Housing and Local Government, only 16 local authorities were selected. These 16 local authorities have already committed toward sustainable cities and reducing carbon emission by 2020 . Charles, Ploeg, \& Mckibbon,(2015), if the sample size is less than 6 , the data obtained is insufficient to make a generalisation and reliable discovery. Beside, Malterud, Siersma, \& Guassora (2015) claimed that "larger information power the sample holds, the lower $\mathrm{N}$ is needed, and vice versa.

The questions script was categorised based on two (2) main themes, which are on participant's background, knowledge and understanding on the topic of this study and current initiatives of practices. This theme developed aligned with research questions and objectives. The first theme elicited understanding on who are participants, job position and working experiences. The second theme aimed to determine knowledge and understanding of the participant relating to the sustainable, while the third, fourth and fifth is to discover the individual perspective on the particular questions. For the final theme, the questioned asked to get the suggestion from the participants on how existing building can upkeep its performance and include in sustainable goal.

For this study, a semi-structured interview was applied as it applies to gain the required data. Besides, this types of interview ensure that relevant contexts are brought into focus so that the situated knowledge can be produced (Edwards \& Holland, 2013). In addition, the interviewees will be informing about the purpose of the research, the need to tape-record the interview and the confidentiality and anonymity of the information given. The interviews lasted between 30 and 50 minutes, and the recordings will be complement with notes taken during the interview and impressions, ideas and thoughts of the interviewer that arose from the interview session.

All the interviews transcribed and manually coded into written form to get the real feel of the data. Next process continued with identified keyword and the meaning of the participant referring to transcribe written form. The keywords then were categorised according to the group of data and this process essential to structure the data and facilitate working with and building knowledge about the data. This process repeated for all the questions. In addition, this process continuously occurred to ensure the keywords categorised under the right coding to avoid redundancy of coding meaning. Through the analytic coding, reoccurring themes identified (Raderbauer, 2011) with the extract of original context interview script keyword.

When the data had been thematising, the analysis using Microsoft Excel begin by calculating the frequency of statement, percentage and ranked claimed by participants for all questions to support the findings of quantitative form support with the script. From this, it derived trend and findings of this study. 
INTERNATIONAL JOURNAL OF ACADEMIC RESEARCH IN BUSINESS AND SOCIAL SCIENCES

Vol. 8, No. 8, August 2018, E-ISSN: 2222-6990 C 2018 HRMARS

\section{Analysis \& Results}

Overall, it revealed various initiatives being practice by local authorities and this indicate local authorities is keeping it phase towards sustainable and making existing building more sustainable. This study identified 16 relevant themes as listed in summary table 1.

Table 1: Sustainable Initiatives

\begin{tabular}{|c|c|c|}
\hline $\begin{array}{c}\text { Sustainable Initiative Practising In } \\
\text { Existing Building }\end{array}$ & $\begin{array}{l}\text { Frequency of } \\
\text { Statement }\end{array}$ & $\begin{array}{c}\text { Percentage } \\
\%\end{array}$ \\
\hline Energy Efficiency & 10 & 14.3 \\
\hline Waste Management & 10 & 14.3 \\
\hline Water Management & 7 & 10.0 \\
\hline Sustainable Operation & 6 & 8.6 \\
\hline Sustainable Commitment & 6 & 8.6 \\
\hline Sustainable Transport & 5 & 7.1 \\
\hline Sustainable Policy / Plan & 5 & 7.1 \\
\hline $\begin{array}{c}\text { Sustainable Knowledge \& } \\
\text { Awareness }\end{array}$ & 5 & 7.1 \\
\hline Sustainable Team \& committee & 4 & 5.7 \\
\hline Sustainable Food Service & 3 & 4.3 \\
\hline $\begin{array}{c}\text { Indoor Air Quality /Natural Air } \\
\text { Ventilation }\end{array}$ & 2 & 2.9 \\
\hline Safety \& Health Occupants & 2 & 2.9 \\
\hline $\begin{array}{l}\text { Resource Management \& } \\
\text { Efficiency }\end{array}$ & 2 & 2.9 \\
\hline Sustainable Design & 1 & 1.4 \\
\hline $\begin{array}{c}\text { Sustainable } \\
\text { Facilities/Infrastructure }\end{array}$ & 1 & 1.4 \\
\hline Sustainable Reporting & 1 & 1.4 \\
\hline Total & 70 & 100 \\
\hline
\end{tabular}

Source: Researcher's Data

\section{a. Energy Efficient}

The statements that outline the activities of energy efficiency implemented in the local authorities existing building. For example, the usage of motion system detector, lighting timer, LED bulb, garden roof parking, district cooling system, retrofit chiller, solar panel, energy audit, energy saving policy which had been mentioned. Among of all initiatives discovered, the largest initiative is $14.3 \%$.

\section{b. Waste Management}

The statement indicates the initiatives relating to the practice of $3 R$ (Reduce, Recycle, Reuse), Composting. All participants mentioned the $3 \mathrm{R}$ practices had been adopted in the day to day operation, recycling of office waste, composting of food left over in the cafeteria and recycling of cooking oil. This initiative contributes $14.3 \%$ among other initiatives. 
INTERNATIONAL JOURNAL OF ACADEMIC RESEARCH IN BUSINESS AND SOCIAL SCIENCES

Vol. 8, No. 8, August 2018, E-ISSN: 2222-6990 @ 2018 HRMARS

\section{c. Water Management}

The initiatives describe the practices of with water savings, water efficiency and rainwater harvesting. The result indicates water management contribute 10\% among the initiatives practise by local authorities in existing building because this initiative contributes to reducing operational cost and reduce the consumption.

\section{d. Sustainable Operation}

This initiative refers to organisational operation that focusing not only economic aspect but embedded environmental and social aspect. For instance, adoption of Environmental Management Standard, Green 5S, International Standard Operation (ISO), Total Quality Management and much other quality management systems. In local authorities, they already adopted ISO, Green $5 S$ and other quality management system that make their operational practices sustainable represent 8.6\%.

\section{e. Sustainable Commitment}

This indicates the commitment of the organisation in achieving the sustainable goal. For instance, local authorities mentioned or claimed to achieve low carbon cities, indicate they committed to participate and be part of sustainable chain. In fact, some local authorities already acquired Green award or any other sustainable acknowledgement locally or worldwide.

\section{f. Sustainable Transport}

This refers to Minimal the usage of transport and carpooling system, using Hybrid Cars, Electric Vehicles, provide charging Station, parking lot for Environmental Friendly Vehicles that relate to transportation. The results indicate $7.1 \%$ which five statements were reveals among the participants.

\section{g. Sustainable Policy / Plan}

Local authorities develop and impose policy/plan for their building and their development in local authority's territories. Five statements mentioned relating to this initiative represent only $7.1 \%$.

\section{h. Sustainable Knowledge \& Awareness}

Knowledge and awareness relating sustainable was instil to al level in the organisation, stakeholders and communities through training, programs, signage, enforcement and mandate or during a monthly meeting or any others platform. This initiative contributes $7.1 \%$ from total percentage indicate how sustainable initiative cultivated in the organisation. Although participants mentioned through training and development program, the important aspect of spreading the knowledge through various ways as mentioned by one of the participants as below and monitoring the implementation to create high sensitivity of awareness in cultivate sustainable practices.

\section{i. $\quad$ Sustainable Team \& committee}

This statement refers to the establishment of the committee, Ambassador and designated team to promote and enforce the sustainability practices. For example in local authorities, they set up a committee, appoint ambassador or representative from each level or department in the building to promote, enforce and cultivate sustainable practices. Four statements which is $5.7 \%$ claimed this initiative as change management for them to cultivate sustainable practices. 
INTERNATIONAL JOURNAL OF ACADEMIC RESEARCH IN BUSINESS AND SOCIAL SCIENCES Vol. 8, No. 8, August 2018, E-ISSN: 2222-6990 @ 2018 HRMARS

\section{j. $\quad$ Sustainable Food Service}

This initiative implemented by local authorities building that have designated floor for cafeteria or cafeteria building prohibited to use plastic or polystyrene as a commitment to preserving the environmental side effect from that usage. The usage of a food container or Tupperware in the cafeteria and no plastic impose to all sellers in the building and communities. This initiative $4.3 \%$ among another statement, implemented according to participants statements.

\section{k. Indoor Air Quality / Natural Air Ventilation}

This initiative refer to activities of cleaning and measuring indoor air quality in indoor to ensure the health of occupants including providing ample indoor air ventilation, using natural air ventilation via windows, provide occupants with lighting control, comfortable temperature, indoor air quality survey, space arrangement, lighting capacity and cleaning ducting. There is a statement made by the participant that indicates cleaning practices is necessary for occupant health conditions.

\section{Safety \& Health Occupants}

This indicates the practices of the organization toward safety and health aspect of the occupants including signage, safety operating procedures and barrier of risk working either by contractor or occupants. Although occupants did mention on the safety aspect of occupants in the building is important, but there is no further explanation relating to this initiative on how the implementation is taking place $2.9 \%$.

\section{m. Resource Management \& Efficiency}

Planning and using resources efficiently indicate how local authorities concern to use available resources (financial, assets, equipment, materials and many others) wisely to minimise any wastage and environmental impact heading organisation toward sustainable Resources Management \& Efficiency which contribute $2.9 \%$ from statement mentioned by participants.

\section{n. Sustainable Design}

This initiative explains the practices of local authorities taking place when retrofitting, refurbishment and renovation activities in existing building that considering the sustainable concept that reduce or avoid unnecessary resource depletion and wastage and creating more comfortable workplace. This initiative represents only $1.4 \%$ from overall statement by participants.

\section{o. Sustainable Facilities/Infrastructure.}

Making facilities and infrastructure in existing building sustainable require huge changes of efforts and financial ability to upkeep the performance of existing facilities and infrastructure through maintenance practices. However, only one statement $1.4 \%$ supports this finding.

\section{p. Sustainable Reporting}

This initiative indicates local authorities reporting platforms of any activities implemented relating to environmental, economic and social benefits that can be relate with organisational strategic planning and shared vision. This initiative is the least mentioned by participants. Only one statement indicate this initiative discover during this study. 
INTERNATIONAL JOURNAL OF ACADEMIC RESEARCH IN BUSINESS AND SOCIAL SCIENCES Vol. 8, No. 8, August 2018, E-ISSN: 2222-6990 @ 2018 HRMARS

\section{Discussion \& Conclusion}

The findings indicate that sustainable practices already implemented in these eight (8) local authorities. Although the practises have implemented, lack of individual competency among participants relating to sustainability knowledge is still occurs. Such conditions urge for improvement regardless of educational background, professional status, years of experience or job function (Saghir \& Sands, 2015). This resulted from lack of exposure, training and development as well as lack understanding relating to sustainable concept and practices in the role of Local Agenda 21. Furthermore, the finding relating to low competencies have direct influence to the practises implemented prove the similar facts as claimed by (Silvius \& Schipper, 2014;Wesselink, Blok, van Leur, Lans, \& Dentoni, 2014; Maletič et al., 2015). Therefore, more exposure for training development on sustainability should be installed to provide depth understanding of sustainability. In this regard, this study provides empirical attempts of sustainable knowledge and understanding in local authority's context.

The findings of this study recorded 16 initiatives discovered compared to Hasim \& Pullen (2011) identified 20 initiatives. The findings of this study have some similar initiatives as claimed by Hasim \& Pullen (2011) but the difference in term of sampling setting and method used. The most significant initiatives specifically were Energy Efficiency and Waste Management were the most common initiatives that implemented in all local authorities existing building. For energy efficiency, this initiative is one of the common tools to make existing building sustainable.

Besides, this initiative also is one of the assessment criteria worldwide in certifying existing building as sustainable building. This because, energy savings and efficiency contribute to the higher saving in monthly utility cost and most common initiatives to make existing building sustainable (Filippi \& Sirombo, 2015; Rughooputh, Cheeneebash, \& Mungroo, 2014;KOÇ, 2014; Abdallah et al., 2013 and Hasim \& Pullen,2011). Thus, it never doubts an energy efficiency initiative is a respond to rising energy cost and awareness to preserve environment and enforcement of savings practices. The guideline by Federal Government and Government initiatives introduced by Suruhanjaya Tenaga (Energy Commission) and SEDA (Sustainable Energy Development Authority) to embark on energy efficient for the past five years have shown the outcome.

Meanwhile, waste management implementation getting more commons due to $5 \mathrm{~S}$ practices widely adopted and become one of the criteria assessments of star rating (assessment of Malaysia local authorities Service Delivery) which introduced by Ministry of Urban Wellbeing, Housing and Local Government, Malaysia. Other initiatives were found to be less significant, but the practices may also contribute to the development of sustainable building. Therefore, local authorities should explore and adopt other initiatives through the adoption of various initiative used from other develop countries. Besides that, local authorities should encourage knowledge sharing practises, promote best practices that currently practices by other local authorities in making the building and the occupant's healthier, environmental betterment including economic gain.

The least initiatives mentioned by the participant are sustainable reporting practices although some of them do report their sustainable practices. Although this initiative is the least mentioned during the interview, researchers believe that there is reporting of sustainable activities through (sustainable corner, bulletin, annual report, web site, pamphlet, electronic advertising) that publicise to the public 
but not mentioned during the interview session. With regard to this discovery of 16 initiatives tabulated, among the local authorities existing building, none of the building obtained sustainable existing building certifications. This demand the changes that should derived the local authorities to obtain the certification. These findings also indicate that the practices are still low among local authorities claimed to be sustainable cities by 2020 which could reflect that the rest of local authorities that is far more behind to venturing in sustainable practices. Furthermore, this indicates that local authorities' role to cultivate sustainably is very weak, and the internal grass root of the organisation understanding on sustainability is still poor.

In fact, the enforcement to impose to other building owners to transform existing building to sustainable building will become a major challenge for local authorities as they actually poor in becoming the icon of sustainable existing building model to the others. Overall, the practices of sustainable initiatives toward sustainable building have strong correlation with the knowledge and understanding of the managers (participants). The poor practices achievement is due to lack of knowledges on sustainable and the application to the existing building and daily operation (Sun, Geelhoed, Caleb-Solly, 2015). However, Jailani, Reed, James (2015) discover contradict findings due to different in building setting and was conducted in develop country.

\section{Conclusion}

Overall, sustainable practices are no longer a jargon practice to local authorities in Malaysia. It is already applicable and become part of the practices. However, this discovery of current initiatives practices indicates local authority's role in championing existing building transformation is still low. Therefore, this study recommended that the government and mainly local authorities to instil indepth knowledge of global condition and its associated to sustainability practices. The continuing education at the grass root of the organizational structure should be practiced to enhance the existing condition of sustainable practices. Since this study revealed the existing practices in selected local authorities existing building comprises of office buildings, assets and other facilities. Therefore it would be beneficial to extend the study to all others local authorities in Malaysia. Furthermore, since the sustainability practices have been implemented by local authorities and possibility main goal are achievable, it is recommended that the study of longitudinal of sustainable initiative conducted to investigate the effectiveness of the practices.

\section{Corresponding Author}

\section{Sr Dr Mohamad Suffian Hasim}

Malaysia

Email: moham315@salam.uitm.edu.my

Head of Centre of Studies, Senior Lecturer Building Surveying

Faculty of Architecture, Planning \& Surveying

Universiti Teknologi MARA

40450 Shah Alam, Selangor, MALAYSIA 
INTERNATIONAL JOURNAL OF ACADEMIC RESEARCH IN BUSINESS AND SOCIAL SCIENCES

Vol. 8, No. 8, August 2018, E-ISSN: 2222-6990 @ 2018 HRMARS

\section{References}

Adeyemi, A., Martin, D., \& Kazim, R. (2014). Elimination of Waste and Inefficient Facilities in Existing Buildings for Sustainability in Developing Nations. International Journal of Architecture and Urban Development, 4(1), 5-16.

Akadiri, P. O., Chinyio, E. a., \& Olomolaiye, P. O. (2012). Design of A Sustainable Building: A Conceptual Framework for Implementing Sustainability in the Building Sector. Buildings, 2(2), 126-152. https://doi.org/10.3390/buildings2020126

Aksamija, A. (2015). Regenerative Design of Existing Buildings for Net-Zero Energy Use. Procedia Engineering, 118, 72-80. https://doi.org/10.1016/j.proeng.2015.08.405

Atkinson, D. (2002). Local Government, Local Governance and Sustainable Development: Getting the Parameters Right. Sustainable Development. Retrieved from http://seg.fsu.edu/Library/Local_Government, _Local_Governance_and_Sustainable_Development__Local_Government, _Local_Governance_and_Sustainable_Development_-_Entire_eBook.pdf

Chan, E. (2014). Building Maintenance Strategy : A Sustainable Refurbishment Perspective. Universal Journal of Management, 2(1), 19-25. https://doi.org/10.13189/ujm.2014.020103

Chili, N. S., \& Xulu, N. (2015). The role of local government to facilitate and spearhead sustainable tourism development. Problems and Perspectives in Management, 13(4), 27-31. Retrieved from http://www.scopus.com/inward/record.url?eid=2-s2.0-

84955299496\&partnerlD=40\&md5=42856cb546b034db7c955beb0581da2c

Das, O., Bera, P., \& Moulick, S. (2015). Water Conservation Aspects of Green Buildings, 75-79. Retrieved from http://esatjournals.net/ijret/2015v04/i25/IJRET20150425012.pdf

Drake, D. F., \& Spinler, S. (2013). Sustainable Operations Management: An Enduring Stream or a Passing Fancy? Manufacturing \& Service Operations Management, 15(4), 689-700. https://doi.org/10.1287/msom.2013.0456

Durmus-pedini, A., \& Ashuri, B. (2010). An Overview of the Benefits and Risk Factors of Going Green in Existing Buildings. International Journal of Facility Management, 1(1), 1-15.

Edwards, R., \& Holland, J. (2013). What is Qualitative Interviewing? "What is?" Research Methods Series. https://doi.org/10.5040/9781472545244

Engel-Yan, J., Kennedy, C., Saiz, S., \& Pressnail, K. (2005). Toward sustainable neighbourhoods: the need to consider infrastructure interactions. Canadian Journal of Civil Engineering, 32(1), 45-57. https://doi.org/10.1139/104-116

Filippi, M., \& Sirombo, E. (2015). Green rating of existing school facilities. Energy Procedia, 78, 3156-3161. https://doi.org/10.1016/j.egypro.2015.11.773

Forum, W. E., \& 2014. (2014). New Growth Models : Challenges and steps to achieving patterns of more equitable, inclusive and sustainable growth.

Gang, W., Wang, S., Xiao, F., \& Gao, D. (2015). Performance Assessment of District Cooling System Coupled with Different Energy Technologies in Subtropical Area. Energy Procedia, 75, 1235-1241. https://doi.org/10.1016/j.egypro.2015.07.166

Getter, K. L., \& Rowe, D. B. (2006). The Rolde of Extensive Green Roofs in Sustainable Development. 
INTERNATIONAL JOURNAL OF ACADEMIC RESEARCH IN BUSINESS AND SOCIAL SCIENCES

Vol. 8, No. 8, August 2018, E-ISSN: 2222-6990 @ 2018 HRMARS

HortScience, 41(5), 1276-1285.

Gilmer, L., Ap, L., Hughel, G., Engineer, P., Baseline, C. Y., \& Use, W. (2008). Improving Water Efficiency in Your Building, 16(4), 1-4.

Gimenez, C., Sierra, V., \& Rodon, J. (2012). Sustainable operations: Their impact on the triple bottom line. International Journal of Production Economics, 140(1), 149-159. https://doi.org/10.1016/j.ijpe.2012.01.035

GSA (General Services Administration). (2011). A Report of the United States General Services Administration The Benefits and Challenges of Green Roofs on Public and Commercial Buildings, (May). Retrieved from http://www.gsa.gov/portal/mediald/158783/fileName/The_Benefits_and_Challenges_of_Green_Roofs _on_Public_and_Commercial_Buildings.action

Hashim, N. (2015). \& Planning for Low Carbon. In Shah Alam towards Low Carbon Cities 2030.

Hasim, M., \& Pullen, S. (2011). Comparative analysis of University websites for indicators of sustainability practises : Australia and Malaysia.

Hayter, S. J., \& Kandt, A. (2011). Renewable Energy Applications for Existing Buildings. 48th AiCARR International Conference Baveno-Lago Maggiore, (September 22-23).

J. Ring, M., Lindner, D., F. Cross, E., \& E. Schlesinger, M. (2012). Causes of the Global Warming Observed since the 19th Century. Atmospheric and Climate Sciences, 2(4), 401-415. https://doi.org/10.4236/acs.2012.24035

Jadhav, A., \& Chandwadkar, D. M. (2016). Optimized Energy Efficient Lighting System For Green Buildings, 2319-2322.

Jaehn, F. (2015). Sustainable Operations. European Journal of Operational Research, 253, 243-264. https://doi.org/10.1016/j.ejor.2016.02.046

Joustra, C. (2010). An Integrated Building Water Management Model for Green Building.

KOÇ, H. E. (2014). Environmental Sustainability of University Campuses: a Practical Assessment Tool, 53(9), 1689-1699. https://doi.org/10.1017/CBO9781107415324.004

Lamba, M. K., \& Sanghi, A. (2015). Energy Audit on Academic Building, 3(4), 600-604.

Li, H. R. (2016). Study on Green Transportation System of International Metropolises. Procedia Engineering, 137, 762-771. https://doi.org/10.1016/j.proeng.2016.01.314

Makmor, M., Ismail, Z., Hashim, R., \& Nasir, N. M. (2012). Malaysia under the Purview of the United Nations and Agenda 21. World Academy of Science, Engineering and Technology, International Science Index 72, Internationa/|rJournal of Social, Human Science and Engineering, 6(12), 80-84.

Maletič, M., Maletič, D., Dahlgaard, J. J., Dahlgaard-Park, S. M., \& Gomišcek, B. (2015). Do corporate sustainability practices enhance organizational economic performance? International Journal of Quality and Service Sciences, 7(2-3), 184-200. https://doi.org/10.1108/IJQSS-02-2015-0025

Malterud, K., Siersma, V. D., \& Guassora, A. D. (2015). Sample Size in Qualitative Interview Studies: Guided by Information Power. Qualitative Health Research, (November), 1-8. https://doi.org/10.1177/1049732315617444

Menaria, D. S. (2014). - STUDY OF ENERGY EFFICIENT LED LIGHTING SCHEMES CONTEXT FOR, 2(8). 
INTERNATIONAL JOURNAL OF ACADEMIC RESEARCH IN BUSINESS AND SOCIAL SCIENCES

Vol. 8, No. 8, August 2018, E-ISSN: 2222-6990 @ 2018 HRMARS

Murtaza, U. (2015). Relationship Between Emissions of Human Activities and Ozone Layer Depletion, (Ph 560).

Nwankwoala, H. N. L. (2015). Causes of Climate and Environmental Changes: The Need for EnvironmentalFriendly Education Policy in Nigeria. Journal of Education and Practice, 6(30), 224-234. Retrieved from http://ezproxy.wheaton.edu/login?url=http://search.ebscohost.com/login.aspx?direct=true\&db=eric\& AN=EJ1081366\&site=ehost-live

Patil, N., \& Wani, A. C. (2016). Review on Energy Efficient Intelligent Lighting System, 433-436.

Rácz, D. A. (2012). Why Invest in Energy Efficiency? The Example of Lighting. Journal of Environmental Sustainability, 2(1), 1-17. https://doi.org/10.14448/jes.02.0001

Raderbauer, M. (2011). The importance of sustainable business practices in the viennese accommodation industry. University of Exeter as a Thesis for the Degree of Master of Science, (September).

Rahman, S. R. A., Ahmad, H., Mohammad, S., \& Rosley, M. S. F. (2015). Perception of Green Roof as a Tool for Urban Regeneration in a Commercial Environment: The Secret Garden, Malaysia. Procedia - Social and Behavioral Sciences, 170, 128-136. https://doi.org/10.1016/j.sbspro.2015.01.022

Rajaniemi, M., \& Ahokas, J. (2012). A case study of energy consumption measurement system in broiler production. Agronomiy Research Biosystem Engineering, (1), 195-204.

Rughooputh, R., Cheeneebash, J., \& Mungroo, M. I. (2014). The Impacts, Benefits and Cost of Sustainable Renovation to Existing Buildings in Mauritius and Setting up of Possible Strategies-Two Case Studies. Environmental Management and Sustainable Development, 3(2), 109. https://doi.org/10.5296/emsd.v3i2.6357

Saghir, C., \& Sands, G. (2015). What Do City Planners Need to Know? When Do They Need to Know It? International Journal of Social Science Studies, 3(2), 2015. https://doi.org/10.11114/ijsss.v3i2.652

Shahzad, U. (2015). Global Warming : Causes, Effects and Solutions, 1(4).

Silvius, A. J. G., \& Schipper, R. P. J. (2014). Sustainability in Project Management Competencies: Analyzing the Competence Gap of Project Managers. Journal of Human Resource and Sustainability Studies, 2(2), 4058. https://doi.org/10.4236/jhrss.2014.22005

Society, O. M. (2005). Sustainable Operations Management, 14(4), 482-492. https://doi.org/10.1007/978-3319-14002-5

Sodangi, M., Khamdi, M. F., Idrus, A., Hammad, D. B., \& Ahmedumar, A. (2014). Best practice criteria for sustainable maintenance management of heritage buildings in Malaysia. Procedia Engineering, 77, 1119. https://doi.org/10.1016/j.proeng.2014.07.017

Standar, B. (2005). Waste management in buildings - Code of practice, 3.

United Nations Environment Programme, 2009, \& This. (2009). B uildings and C limate $C$ hange.

Vargas-Hernandez, J., Reza, M., \& Haj Ali, I. F. N. (2013). What is Policy, Social Policy and Social Policy Changing? International Journal of Business and Social Science, 2(10), 287-291. Retrieved from https://hal.archivesouvertes.fr/hal-00817798

Wesselink, R., Blok, V., van Leur, S., Lans, T., \& Dentoni, D. (2014). Individual competencies for managers engaged in corporate sustainable management practices. Journal of Cleaner Production, 106(February 2015), 497-506. https://doi.org/10.1016/j.jclepro.2014.10.093

Wood, B. (2006). The role of existing buildings in the sustainability agenda. Facilities, 24, 61-67. 
INTERNATIONAL JOURNAL OF ACADEMIC RESEARCH IN BUSINESS AND SOCIAL SCIENCES

Vol. 8, No. 8, August 2018, E-ISSN: 2222-6990 @ 2018 HRMARS

https://doi.org/10.1108/02632770610639206

Works, Q. D. of P. (2009). water smart buildings.

Yan-ping, F., Yong, W., \& Chang-bin, L. (2009). Energy-efficiency supervision systems for energy management in large public buildings: Necessary choice for China. Energy Policy, 37(6), 2060-2065. https://doi.org/10.1016/j.enpol.2008.12.033

Zein, A. L. El, \& Chehayeb, N. A. (2015). The Effect of Greenhouse Gases on Earth's Temperature. International Journal of Environmental Monitoring and Analysis, 3(2), 74-79. https://doi.org/10.11648/j.ijema.20150302.16 